\title{
Biological control of Culex (Culex) saltanensis Dyar, (Diptera, Culicidae) through Bacillus thuringiensis israelensis in laboratory and field conditions
}

\author{
João A. C. Zequi ${ }^{1} \&$ José Lopes ${ }^{2}$
}

\author{
${ }^{1}$ Departamento de Agronomia, Universidade Estadual de Londrina. Rua Alagoas 2050, 86020-340 Londrina, Paraná, Brail. \\ E-mail: biologia@unifil.br \\ 2 Departamento de Biologia Animal e Vegetal, Universidade Estadual de Londrina. Caixa Postal 6001, 86051-970 Londrina, \\ Paraná, Brasil. E-mail: jea@uel.br
}

\begin{abstract}
Culex (Culex) saltanensis Dyar, 1928 can become a problem in urban centers because they reproduce abundantly in ponds organically enriched. It is vector of the Plasmodium spp. and Crithidia ricadoi Sibajev et al. 1993. This research verifies the efficacy of Bacillus thuringiensis israelensis on C. saltanensis in two temperature situations, both in laboratory and field conditions. $\mathrm{LC}_{50}$ for $\mathrm{C}$. saltanensis immatures fourth instar, was $0.154 \mathrm{ppm}$ and the $\mathrm{LC}_{95}$ was $0.248 \mathrm{ppm}$ an average temperature of $25.7^{\circ} \mathrm{C}$. When exposed at a constant temperature of $12 \pm 1^{\circ} \mathrm{C}$ and a photoperiod of $14 \mathrm{~L}: 10 \mathrm{D}$, had its susceptibity decreased in 1.50 times in reation to $\mathrm{LC}_{50}$, when compared to room temperature. $B$. thuringiensis israelensis is highly efficient in the control of this mosquito in natural environment with a high level of polluants using the concentration of 2 liters/hectare, with applications every 15 days.

KEY WORDS. Bioassay; mosquito control; immature Culicidae.
\end{abstract}

\begin{abstract}
RESUMO. Controle biológico de Culex (Culex) saltanensis Dyar, (Diptera, Culicidae) através de Bacillus thuringiensis israelensis em condições de laboratório e campo. Culex (Culex) saltanensis Dyar, 1928 pode se tornar um problema nos centros urbanos, porque reproduz abundantemente em lagoas de tratamento de efluentes. Esse mosquito é vetor de Plasmodium spp. e Crithidia ricadoi Sibajev et al. 1993. O objetivo dessa pesquisa foi verificar a eficácia de Bacillus thuringiensis israelensis sobre $C$. saltanensis em condições de temperatura no laboratório e campo. $\mathrm{A} \mathrm{CL}_{50}$ para imaturos de quarto ínstar de $C$. saltanensis foi $0,154 \mathrm{ppm}$ e a $\mathrm{Cl}_{5}$ foi $0,248 \mathrm{ppm}$ em temperatura ambiente média de $25,7^{\circ} \mathrm{C}$. Quando o bioensaio foi conduzido à temperatura constante de $12 \pm 1^{\circ} \mathrm{C}$ e fotoperíodo de $14 \mathrm{~L}: 1 \mathrm{OE}$, a suscetibilidade da larva diminui em 1,50 vezes em relação a $\mathrm{CL}_{50}$, quando comparado a temperatura ambiente. $B$. thuringiensis israelensis é eficiente no controle desse mosquito em seu ambiente natural com altos índices de matéria orgânica, usando 2 litros/hectare com aplicações a cada 15 dias.
\end{abstract}

PALAVRAS-CHAVE. Bioensaio; controle de mosquito; imaturo.

Culex saltanensis Dyar, 1928 can become a problem in urban centers because they reproduce abundantly in ponds orgnically enriched. They also colonize other natural and artificial breeding sites. Culex (Culex) saltanensis Dyar, 1928 was first collected in the state of Rio de Janeiro by LOURENÇO DE Oliveira (1984). In northern Paraná, Brazil, this mosquito was found by LoPES, (1997a, b), although it was identified as Culex bahamenis Dyar \& Knab, 1906.

It is vector of the Plasmodium cathemerium Hartman, 1927 sparrow hemosporidian (GABALDON et al. 1988), and was considered by Lourenço-de-Oliveira \& CASTRo (1991) as a primary vector of Plasmodium juxtanucleare Versiani \& Gomes, 1941, a protozoan which causes malaria in birds. A new tripanossomatyd species - Crithidia ricardoi Sibajev et al. 1993, original host of C. saltanensis, was described by Sibajev et al. (1993).
The control methods for Culicidae can be cultural, by cleaning the breeding place, taking the vegetation away and doing the appropriate handling, according to the species; or chemical, by using organo-phosporated products, which have restricted use to certain places due to its non-specificity and the high resistance rate presented by insects. There is also the possibility of fighting the insect through a biological and integrated control.

The number of vector insects resistant to chemical pesticides, the long duration of their effects, their non-specificity in the target organisms, and their pollutant action in the atmosphere have encouraged researches on alternative biological pesticides, as the use of entomopathogenic Bacillus spp. (Consol et al. 1997). Bacillus thuringiensis israelensis (Bti) is specific for larvae of mosquitoes and black fly species, but differ- 
ent levels of susceptibility are reported. In general, Culex Linnaeus, 1758, species are rather susceptible, followed by Aedes spp. Meigen, 1818, while Anopheles spp. Meigen, 1818 somewhat less susceptible to products based on B. thuringiensis israelensis (MuLLA, 1990). The efficiency of B. thuringiensis israelensis on several species of Culicidae has been verified by LACEY \& LACEY (1981), BeCKER et al. (1992), Brown et al. (1998a, b), Rodrigues et al. (1998), Su \& MulLa (1999), Brown et al. (1999), Nayar et al. (1999), Brown et al. (2000) and Amalraj et al. (2000) among several other researches.

This research verifies the efficacy of $B$. thuringiensis israelensis on $\mathrm{C}$. saltanensis in two temperature situations, both in laboratory and field conditions, taking into account its frequent presence in large organically enriched sites, its potential as a vector of pathogenic agents, and the fact that there is no history of biological control of this species.

\section{MATERIAL AND METHODS}

About 30 rafts of $C$. saltanensis eggs were collected on a weekly basis from an effluent treatment pond of a soft drink factory in Londrina, Paraná.

The eggs were conditioned in a $40 \times 28 \mathrm{~cm}$ tray, $3.5 \mathrm{~cm}$ deep, with $1.800 \mathrm{~mL}$ of well water. They were placed inside an acclimatized incubator (BOD) at $27 \pm 1^{\circ}$ C and a photoperiod of 14L:10D. The immatures were fed daily with $30 \mathrm{mg}$ of “Dog Show" (food for puppies), mill-triturated in particles of approximately $1 \mathrm{~mm}$. After the sixth day of development the larvae, which were already in the $4^{\text {th }}$ instar, were used in bioassays, and no food was added to the trays 24 hours before the test.

Bacillus thuringiensis israelensis Vectobacâ- AS, 1.200 ITU/mg Lot $\mathrm{n}$ 53-040-N9 was used both for laboratory and field tests.

The bioassays were based on LACEY (1997) and the World Health Organization for bacterial Iarvicides for public health use (DRAFT-W Ho 1999). One was done with repetitions in different days when the average temperature was approximately 25.7으, and a natural photoperiod (14L:10D), and the other with a constant temperature of $12 \pm 1$ 으, and a photoperiod of 14L:10D for conditioning in incubator.

Thefield experiment was donein a landfill leachate pond, in the outsskirts of Londrina (51019'11"W, 2355'46"S) Paraná,
Brazil. The pond measured $130 \times 60 \mathrm{~m}\left(7,800 \mathrm{~m}^{2}\right)$ and is highly polluted both by organic material and chemicals. Vectobacâ was used at two liters per hectare, which is the average dosage recommended by the manufacturer for these conditions, with a motorized bomb for sprinkling.

The pond where the field experiment was done was colonized only b C. saltanensis, and the experiment was replicated twice on $24 / X$ to $24 / X 1 / 2000$. Before the application, six points of larvae collection were determined, equally distant in the pond and covering all its diameter. An entomological net with $1 \mathrm{~mm}$ was used for the capture of larvae, as described by LoPES \& LozOVEl (1995). The immatures were collected in a singlethrow of the entomological net at about $30 \mathrm{~cm}$ from the bank. As a reference point, a sample collection was taken before the beginning of the application, and other subsequent collections were systematically taken daily 1-4 after application and again seven and 15 days after application.

In each collection procedure, live larvae were counted. Ten percent of collected larvae were mounted on slides in Hoyer's medium for subsequent identification.

Temperature and precipitation data were supplied by the Agronomic Institute of Paraná (IAPAR), which is approximately $5 \mathrm{~km}$ away from the experiment location.

The laboratory tests were analyzed using Probit analysis, and the respective $\mathrm{LC}_{50}$ and $\mathrm{LC}_{95}$ were calculated.

\section{RESULTS AND DISCUSSION}

We determined from laboratory bioassays that the $\mathrm{LC}_{50}$ for C. saltanensis immatures, fourth instar, was 0.154 (0.1350.232) ppm and the $\mathrm{LC}_{95}$ was 0.248 (0.189-0.701). The $\mathrm{LC}_{95}$ was 1.61 times higher than the respective $L_{50}$ for larvae of the $4^{\text {th }}$ when assays were conducted at 25.7 으 (Tab. I).

Using the same product, NAYAR et al. (1999) reported values of 0.131 and 0.207 ppm respectively for $\mathrm{LC}_{50}$ and $\mathrm{LC}_{90}$ in larvae of Culex nigripalpus Theobald, 1901, in $4^{\text {th }}$ instars. This species belongs to the same sub-genus as $C$. saltanensis and is also found in ponds with polluted water in urban areas. This helps to explain the similar results we report here.

LACEY \& LACEY (1981) reported respective mortality rates of $92 \%$ for Culex (Culex) mollis Dyar \& Knab, 1906; $92.96 \%$ for

Table I. Lethal concentrations ( $\mathrm{LC}_{50}$ and $\mathrm{LC}_{95}$ ) of B. thuringiensis israelensis $(1.200 \mathrm{ITU} / \mathrm{mg})$ on immatures of $4^{\text {th }}$ instars of $\mathrm{C}$. saltanensis, kept at an average temperature of $25.7^{\circ} \mathrm{C}$ in the bioassay and environmental photoperiod (14L: 10D) with ( $\mathrm{n}=25$ larvae/pot).

\begin{tabular}{ccccccc}
\hline Repetitions & $\mathrm{LC}_{50}(\mathrm{ppm})$ & $\begin{array}{c}\text { Lower Limit } \\
\text { (Confidence interval) }\end{array}$ & $\begin{array}{c}\text { Upper Limit } \\
\text { (Confidence interval) }\end{array}$ & $\mathrm{LC}_{95}$ (ppm) & $\begin{array}{c}\text { Lower Limit } \\
\text { (Confidence interval) }\end{array}$ & $\begin{array}{c}\text { Upper Limit } \\
\text { (Confidence interval) }\end{array}$ \\
\hline 1 & 0.152463 & 0.135557 & 0.222450 & 0.241824 & 0.184515 & 0.694718 \\
2 & 0.145205 & 0.132875 & 0.173557 & 0.210780 & 0.175525 & 0.339905 \\
3 & 0.143506 & 0.126648 & 0.189723 & 0.261490 & 0.195301 & 0.573263 \\
4 & 0.143918 & 0.128226 & 0.185389 & 0.246682 & 0.189633 & 0.498011 \\
5 & 0.182574 & 0.153139 & 0.388214 & 0.280374 & 0.201531 & 1.398270 \\
Average & 0.154000 & 0.135000 & 0.232000 & 0.248000 & 0.189000 & 0.701000 \\
\hline
\end{tabular}


Limatus durhamii Theobald, 1901 and Limatus flavisetosus De Oliveira Castro, 1935; and 63.33\% for Trichoprosopon digitatum (Rondani, 1848); using B. thuringiensis israelensis $1000 \mathrm{UTI} / \mathrm{mg}$ in the laboratory. The same authors verified with the same preparation a $\mathrm{LC}_{50}$ and $\mathrm{LC}_{95}$ of 0.042 and 0.33 ppm respectively for late $3^{\text {rd }}$ - early $4^{\text {th }}$ instar of $C$. quinquefasciatus.

The mosquito susceptibility increases or decreases according to the species, and also due to the influence of abiotic conditions such as pollution, water depth turbidity, temperature, associated microflora, ionic composition of water, presence of larval food, an canopy and biotic conditions of the environment (LACEY \& UNDEEN 1986).

Culex saltanensis, when exposed to $B$. thuringiensis israelensis at a constant temperature of $12 \pm 1^{\circ} \mathrm{C}$ and a photoperiod of 14L:10D, had its susceptibility decreased in 1.5 times in relation to $\mathrm{LC}_{50}$, when compared to room temperature (Tab I and II). In these conditions, the $\mathrm{LC}_{95}$ was 1.68 times higher in relation to the $\mathrm{LC}_{50}$ (Tab. II). Both the kinetics of toxin activation and feeding rate (hence the amount of toxin consumed) are governed by ambient temperatures.

LACEY \& OldACRE (1983) reported an direct and positive relationship between mortality and temperature with early $4^{\text {th }}$ instar Culex quinquefasciatus exposed to $3.4 \times 10^{4}$ viable spores/mL of $B$. thuringiensis $(\mathrm{H}-10)$ at $17.7,24.3$ and 31 으.

BECKER et al. (1992) found a distinct difference in the effectiveness of Bti between $5^{\circ} \mathrm{C}$ and $8^{\circ} \mathrm{C}$ in the $2^{\text {nd }}$ and $4^{\text {th }}$ instars of Aedes vexans (M eigen, 1830). In low temperatures there is a reduction of water filtering by the larvae, which suggests that the amount of product used with low temperatures should be increased. The LC $_{95}$ was 1.56 times higher in bioassays with immatures kept at low temperatures than in the environment (Tabs I and II).

NAYAR et al. (1999) report an $\mathrm{LC}_{50}$ of $0.152,0.139$ and $0.140 \mathrm{ppm}$ in bioassays kept at $15^{\circ} \mathrm{C}, 25^{\circ} \mathrm{C}$ and $35^{\circ} \mathrm{C}$ respectively, for $C$. nigripalpus $4^{\text {th }}$ instar exposed to Vectobac ${ }^{\circledR} 12$ AS - $1.200 \mathrm{UTI} / \mathrm{mg}$, in 24 hours. BRown et al. (2000), using B. thuringiensis israelensis with $1.279 \times 10^{9} \mathrm{ITU} / \mathrm{mg}$, verified that a LC $_{95}$ for Culex annulirostris Skuse, 1889 larvae of the $3^{\text {rd }}$ instar were among $0.013 \times 10^{9}\left(0.01\right.$ to $\left.0.02 \times 10^{9}\right) \mathrm{ITU} / \mathrm{mg}$ in laboratory conditions.
In field conditions Vectobac ${ }^{\circledR}$ AS was efficient in the control of this mosquito (Fig. 1), using the average concentration recommended for the product (two liters / hectare) for highly polluted environments. Before the first application 12,146 C. saltanensis immatures were collected. There was $100 \%$ mortality of larvae 24 hours after application of the product. The larva index remained low for up to 15 days. The second application continued to control $100 \%$ of the immatures present in this pond (Fig. 1).

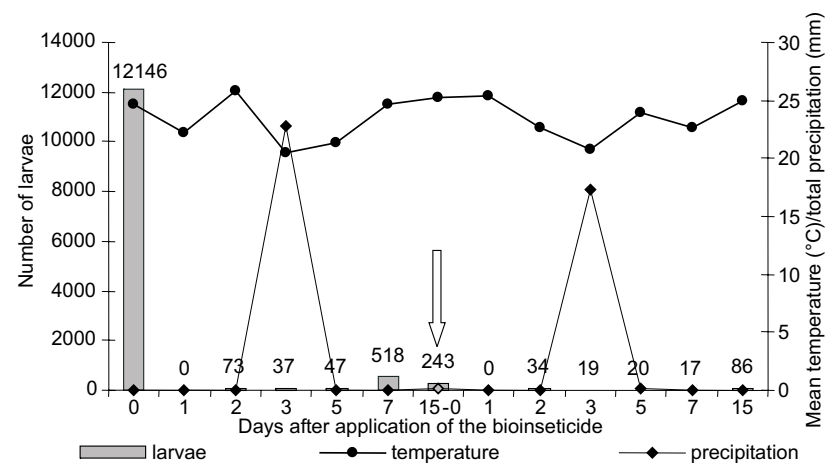

Fig. 1. Number of $C$. saltanensis larvae collected before and after the application of Vectobac ${ }^{\circledR}$ AS (1,200 ITU/mg), 2 liters/hectare after two consecutive applications at the landfill leachate pond in Londrina, Paraná, Brazil.

The application of Vectobac every 15 days can offer efficient results for the control of this species. These data are important because there no record of control for this mosquito until now.

BRown et al. (1998a) controlled $3^{\text {rd }}$ instar Culex sitiens, Wiedeman, 1828 larvae using 0.0077 liters/hectare of Vectobac 12 AS in laboratory conditions to reach the $\mathrm{LC}_{50}$, and 0.011 liters / hectare to reach the $\mathrm{LC}_{95}$. In this experiment in Londrina, there was a mortality rate of $100 \%$ of larvae, 24 hours after the application of the product in a 2.0 liters / hectare concentration in field.

Table II. Lethal concentrations ( $\mathrm{LC}_{50}$ and $\mathrm{LC}_{95}$ ) of B. thuringiensis israelensis ( $\left.1.200 \mathrm{ITU} / \mathrm{mg}\right)$ on immatures of $4^{\text {th }}$ instars of $\mathrm{C}$. saltanensis, maintained in the bioassay at a constant temperature of $12 \pm 1$ o $C$ and photoperiod $14 \mathrm{~L}: 10 \mathrm{D}$ ( $\mathrm{n}=25$ larvae/pot).

\begin{tabular}{ccccccc}
\hline Repetitions & $\mathrm{LC}_{50}(\mathrm{ppm})$ & $\begin{array}{c}\text { Lower Limit } \\
\text { (Confidence interval) }\end{array}$ & $\begin{array}{c}\text { Upper Limit } \\
\text { (Confidence interval) }\end{array}$ & LC $_{95}$ (ppm) & $\begin{array}{c}\text { Lower Limit } \\
\text { (Confidence interval) }\end{array}$ & $\begin{array}{c}\text { Upper Limit } \\
\text { (Confidence interval) }\end{array}$ \\
\hline 1 & 0.226313 & 0.210190 & 0.252941 & 0.304320 & 0.268293 & 0.380083 \\
2 & 0.235985 & 0.206157 & 0.332931 & 0.437540 & 0.317333 & 1.130193 \\
3 & 0.243057 & 0.219600 & 0.288563 & 0.353388 & 0.295566 & 0.497584 \\
4 & 0.236977 & 0.204310 & 0.348851 & 0.474337 & 0.330697 & 1.402827 \\
5 & 0.211426 & 0.191136 & 0.259309 & 0.367833 & 0.287613 & 0.679261 \\
Average & 0.231000 & 0.206000 & 0.297000 & 0.387000 & 0.300000 & 0.818000 \\
\hline
\end{tabular}

Revista Brasileira de Zoologia 24 (1): 164-168, março 2007 
Brown et al. (1999) compared two organophosphorates, a growth regulator and $B$. thuringiensis israelensis, on Aedes vigilax (Skuse, 1889), in Queensland, Australia, and verified that the biological product (Bti) was efficient in the control of the mosquito in laboratory and field conditions, and it did not affect the survival of Leander tenuicornis (Decapoda, Palaemonidae) a non target species with the environment. It also did not affect the quality of the water, while the organophosphorates influenced its $\mathrm{pH}$ and turbidity.

SKovmand \& SANOGO (1999), whiletesting Bacillus sphaericus and $B$. thuringiensis israelensis in cesspools and rain puddles, in Burkina Faso, Ouagadougou, Africa, reported that B. sphaericus applied at the rate of $3.0 \mathrm{~g} / \mathrm{m}^{2}$ reduced C. quinquefasciatus $99 \%$ for at least 28 days in cesspits, whereas the same dosage of two Bti granules and comercial liquid formulations of Bs and Bti gave 95\% control for 8-14 days. The levels of control obtained with the two liquid products were not different. B. thuringiensis had a reported inferiority compared to $B$. sphaericus in polluted waters. This was due to the low dosage of $\mathrm{B}$. thuringiensis used. Nevertheless, it had a larger action spectrum, killing $C$. quinquefasciatus, Culex decens Theobald, 1901 and also Culex cinereus Theobald, 1901.

The experiment a polluted habitat in Londrina proved Bti to be efficient, and somewhat different from other results reported in the literature that show lower efficiency of Bti in highly-polluted breeding places, when the average dosage recommended by the manufacturer was used in locations.

\section{CONCLUSIONS}

Bacillus thuringiensis israelensis (Vectobac ${ }^{\circledR}$ AS - 1.200 ITU/mg) controls C. saltanensis $4^{\text {th }}$ instar larvae with an LC $_{50}$ of 0.154 ppm and an LC $_{95}$ of 0.248 at room temperature. At $12 \pm$ $1^{\circ} \mathrm{C}$, this product presented a decrease in efficiency of about 1.50 times in relation the to $\mathrm{LC}_{50}$ at room temperature under controlled laboratory conditions.

Vectobac ${ }^{\circledR}$ AS $-1.200 \mathrm{ITU} / \mathrm{mg}$ is highly efficient in the control of this mosquito in its natural environment with a high level of pollutants using the concentration of 2 liters / hectare, with applications every 15 days.

\section{ACKNOWLEDGMENTS}

We thank Lawrence A. Lacey (USDA, ARS, YARL), for his review of the manuscript and provided helpful comments.

\section{REFERENCES}

Almalraj, D.D.; S.S. Sahu; P. Jambulingam; D. Boopathi; M. Kalyanasundaram; \& P.K. DAS. 2000. Efficacy of aqueosus suspension and granular formulations of Bacillus thuringiensis (Vectobac) against mosquito vectors. Acta Tropica 75: 243-246.

Becker, N.; M. Zgomba; M. Ludwig; D. Petric \& F. Rettich. 1992. Factors influencing the activity of Bacillus thuringiensis sorovar israelensis treatments. Journal of the American
Mosquito Control Association 8 (3): 285-289.

Brown, M.D.; T.K.W. DarRan \& H.K. BRIAN. 1998a. Laboratory and field evaluation of efficacy of Vectobac ${ }^{\circledR} 12$ AS against Culex sitiens (Diptera: Culicidae) Iarvae. Journal of the American Mosquito Control Association 14 (2): 183-185.

Brown, M.D.; T. Darran \& H.K. Brian. 1998b. Acute toxicity of selected pesticides to the pacific blue-eye, Pseudomugil signifer (Pisces). Journal of the American Mosquito Control Association 14 (4): 463-466.

Brown, M.D.; T. Darran; M. Paul; G.G. Jack \& H.K. Brian. 1999. Laboratory and field evaluation of the efficacy of four insecticides for Aedes vigilax (Diptera: Culicidae) and toxicity to the nontarget shrimp Leander tenuicornis (Decapoda: Palaemonidae). Journal of Economic Entomology 92 (5): 1045-1051.

Brown, M.D.; M.W. Tonya; G. Susannah; G.G. Jack; P. David \& H.K. BRIAN. 2000. Toxicity of insecticides for control of freshwater Culex annulirostris (Diptera: Culicidae) to the nontarget shrimp, Caradina indistincta (Decapoda: Atyidae). Journal of Economic Entomology 93 (3): 667-672.

Consoli, R.A.G.B.; S.S. de Bernadete; A.L. Marlúcia; F.C.S. Nágila; R. Leon; M.B.S. Cláudia; S.A.A. Regina \& F.F.C. NídiA. 1997. Efficacy of a new formulation of Bacillus sphaericus 2362 against Culex quinquefasciatus (Diptera: Culicidae) in Montes Claros, Minas Gerais, Brazil. Memórias do Instituto Oswaldo Cruz 92 (4): 571-573.

Draft-Who. 1999. Determination of the Toxicity of Bacillus thuringiensis subsp. israelensis and $\mathrm{B}$. sphaericus products, $\mathrm{p}$. 29-33. In: WHO/CDS/CPC/WHOPES/99.2 (Eds). Guideline specifications for bacterial larvicides for public healt use. Geneva, 33p.

Gabaldon, A.; G. Ulloa \& N. Zerpa. 1988. Plasmodium cathermerium, cepa de Icteridae inoculable a palomas, patos y pavos; sus vectores y utilidad en enseñanza e investigación. Boletin de la Dirección de Malariologia y Saneamiento Ambiental 28: 53-68.

LACEY, L.A. 1997. Bacteria: Laboratory biossay of bacteria against aquatic insects with emphasis on larvae of mosquitoes and black flies, p. 79-90. In: L.A. LACEY (Ed.). Manual of techniques in insect pathology. London, Academic Press, 409p.

LACEY, L.A. \& A.H. UnDEEN. 1986. Microbial control of black flies and mosquitoes. Annual Review Entomology 31: 265-296.

LACEY, L.A. \& J.M. LACEY. 1981. The larvicidal activity of Bacillus thuringiensis var. israelensis $(\mathrm{H}-14)$ against mosquitoes of the central Amazon basin. Mosquito News 41 (2): 266-270.

LACEY, L.A. \& S.L. OLDACRE. 1983. The effect of temperature, larval age, and species of mosquitoes activity of an isolate of Bacillus thuringiensis var. darmstadiensis toxic for mosquito larvae. Mosquito News 43 (2): 176-180.

LOPES, J. 1997a. Ecologia de Mosquitos (Diptera, Culicidae) em criadouros naturais e artificiais de área rural do norte do estado do Paraná, Brasil. VII. Coexistência das espécies. Iheringia, Série Zoologia (83): 91-97.

Revista Brasileira de Zoologia 24 (1): 164-168, março 2007 
LOPES, J. 1997b. Ecologia de Mosquitos (Diptera, Culicidae) em criadouros naturais e artificiais de área rural do norte do estado do Paraná, Brasil. VI. Coletas de larvas no peridomicílio. Revista Brasileira de Zoologia 14 (3): 571-578.

LoPES, J. \& A.L. Lozovel. 1995. Ecologia de mosquitos (Diptera: Culicidae) em criadouros naturais e artificiais de área rural do Norte do Estado do Paraná, Brasil. I - Coletas ao longo do ribeirão. Revista de Saúde Pública 29 (3): 183-191.

LOUREnço-DE-Oliveira, R. 1984. Alguns aspectos da Ecologia dos mosquitos (Diptera: Culicidae de uma área de planície (Granjas Calábria), em Jacarepaguá, Rio deJaneiro. I. Freqüência comparativa das espécies em diferentes ambientes e métodos de coleta. Memórias do Instituto Oswaldo Cruz 79 (4): 479-490.

Lourenço-de-Oliveira, R. \& F.A. De CAstro. 1991. Culex saltanensis Dyar, 1928. Natural vector of Plasmodium juxtanucleare in Rio de Janeiro, Brasil. Memórias do Instituto Oswaldo Cruz 86: 87-94.

Mulla, M.S. 1990. Activity, field efficacy, and use of Bacillus thuringiensis israelensis against mosquitoes, p. 134-160. In: H. DE Barjac \& D. Sutherland (Eds). Bacterial Control of mosquitoes \& blackflies. New Brunsuvich, Rutgers University Press, 349p.
Nayar, J.K.; J.W. Knight; A. Ali; D.B Carlson; O.P.D. Bryan. 1999. Laboratory evaluation of biotic and biotic factors that may influence larvicidal activity of Bacillus thuringiensis serovar. Israelensis against two Florida mosquito species. Journal of the American Mosquito Control Association 15 (1): 32-42.

Rodrigues, I.B.; P.T. WANDERLI \& M.C.S.D. José. 1998. Studies on the Bacillus sphaericus Iarvicidal activity against Malarial Vector Species in Amazonia. Memórias do Instituo Oswaldo Cruz 93 (4): 441-444.

Sibajev, A.; R.S. Pacheco; M.J. Soares; E. Cupolillo; A.B. dos santos \& H. Momen. 1993. Crithidia ricardoi sp.n. a new species of trypanossomatidae isolated from Culex saltanensis Dyar, 1928 (Diptera, Culicidae). Memórias do Instituto Oswaldo Cruz 88 (4): 541-545.

Skovmand, O. \& E. SAnogo. 1999. Experimental Formulations of Bacillus sphaericus and $B$. thuringiensis israelensis against Culex quinquefasciatus and Anopheles gambiae (Diptera: Culicidae) in Burkina Faso. Journal of Medical Entomology 1: 62-67.

Su, T. \& S. Mulla. 1999. Microbial agents Bacillus thuringiensis spp. israelensis and Bacillus sphaericus Suppress Eutrophication, Enhance Water Quality, and Control Mosquitoes in Microcosms. Environmental Entomology 28: 761-767.

Received in 27.Vl.2006; accepted in 05.III.2007. 